\title{
The Conservation Status of Grassland Habitats Belonging to Protected Areas from Oltenia 'Natura 2000' Site, Romania
}

\author{
Daniel RĂDUT,OIU
}

University ofCraiova, Faculty of Agriculture and Horticulture, 19 Libertății, 200583Craiova, Romania: radutoiudaniel@yahoo.com

\begin{abstract}
In the present paper, are rendered the results of the research referring to the conservation status of the grasslands from two sites 'Natura 2000' located in Oltenia region, in South-Western part of Romania: ROSCI0202 Oltenia Forest Steppe and ROSCI0039 Ciuperceni - Desa. Within these sites, there are five habitats: $62 \mathrm{C} 0^{*}$ Ponto-Sarmatic steppes, $6260^{*}$ Pannonic sand steppes, 6440 Alluvial meadows of river valleys of the Cnidion dubii, 6510 Lowland hay meadows (Alopecurus pratensis, Sanguisorba officinalis) and 1530* Pannonic salt steppes and salt marshes. The investigation of the conservation status of these habitats was carried out by assessing their conservation status at EU level, namely by assigning them to one of the four categories - "favourable", "unfavourable-inadequate", "unfavourable-bad", and "unknown" - according to the stated attributes for each habitat, to the threats of destruction and to the dangers that may lead to their destruction or disappearance. By applying the evaluation matrix of the conservation state of the five habitats from the two sites Natura 2000, only three of the five studied habitats have a good conservation status: 62C0* Ponto-Sarmatic steppes, 6260* Pannonic sand steppes, 6440 alluvial meadows of river valleys of the Cnidion dubii. The habitat $1530^{*}$ Pannonic salt steppes and salt marshes have a good-moderate status while 6510 Lowland hay meadows (Alopecurus pratensis, Sanguisorba officinalis) has amoderate-poor status. Referring to the characteristic structure and functions to the type of habitat, the research revealed that in numerous areas occupied by the five habitats good conservation conditions are not good.
\end{abstract}

Keywords: grasses, protected area, steppes, vegetation

\section{Introduction}

The issue of rare plants and habitats from the southern part of Oltenia (South-Western part of Romania) is far from being solved even if it is quite stringent. The surfaces covered by grasslands from the studied protected areas (ROSCI0202 Oltenia Forest Steppe and ROSCI0039 Ciuperceni - Desa) that are part of the sites of community importance of Natura 2000 network, are within the perimeter of many settlements from Dolj County (Ciupercenii Noi, Desa, Radovan, Perişor, Mărăcinele, Tencănău, Castrele Traiane, Verbicioara and Carpen). As a result of 'Natura 2000' research, there were identified five types of habitats, types of semi-natural grasslands of high value.

The studied area (situated in Oltenia region, in SouthWestern part of Romania) is characterized by a great diversity of landforms (hills, plains) and by various aspects and gradients of slope, together with heterogeneity of soils and the anthropological and zoological activity of traditional type.

There are just a few floristic and vegetation studies referring to the surfaces covered by these habitats (Buia, 1959; Cârțu, 1968; Ionescu, 1971; Popescu et al., 2003; Ciocârlan 2000, 2009; Dihoru and Negrean, 2009; Sârbu et al., 2013). The floristic and vegetation analysis of the two sites highlight a high phytodiversity.

\section{Materials and Methods}

The material used for this work consisted, on one hand, in the analysis of different scientific works containing data from the studied areas, and the other hand the used material also consists in the analysis of the data obtained from our own field trips made from 2012 to the present.

The assessment of the conservation status considers the natural habitats of Annex I of the EU Habitats Directive identified in the investigated area (Habitats Directive 92/43/EEC, 2015). The codes and the description of the habitat types correspond to 'Natura 2000' and the Romanian system of classification (Doniță et al., 2005, 2006; Gafta and Mountford, 2008).

In a natural habitat, the conservation status is derived from all the factors acting upon it and upon the characteristic species, which may affect long-term distribution, structure and functions, as well as the survival of the characteristic species. The parameters used to calculate the conservation status of a habitat are: natural distribution area, area covered by the habitat, specific structure and functionality of the habitat, and future prospects, which are associated with it (Combroux and Schwoerer, 2007). 
The conservation status is considered "favourable" when the following conditions exist: the natural range of the habitat and the areas covers within that range are stable or increasing; the habitat has the specific structure and functions necessary for its long-term survival, and the probability of maintaining favourable conditions in the foreseeable future is high; the characteristic species of the habitat are in a state of favourable conservation.

The fact that a habitat type is not threatened does not mean that it has a favourable conservation status. 'Unfavourable conservation status' is divided into two classes: "unfavourableinadequate" for situations that require a change in policy or management to bring the type of habitat or species to a favourable conservation status, but there is no danger of extinction in the foreseeable future (e.g. 50-100 years); and "unfavourable-bad" for situations where the type of habitat or species is in danger of extinction in the foreseeable future (e.g. 50100 years).

For all situations where insufficient information exists to make a proper assessment, conservation status is considered "unknown". For the graphical representation of the conservation status, a colour-coding system was adopted: red for "unfavourable-bad"; orange for "unfavourable-inadequate"; green for "favourable"; grey for "unknown".

In order to investigate these grassland habitats, numerous relevées were made in many of their representative areas. The classification of the vegetation of these habitats was made according to scientific literature from Romania (Sanda et al., 1980; Sanda et al., 2001; Sanda, 2002).

\section{Results and Discussions}

In the two 'Natura 2000' studied sites, there were identified five types of praticole habitats: $62 \mathrm{C}^{*}$ Ponto-Sarmatic steppes, $6260^{*}$ Pannonic sand steppes, 6440 alluvial meadows of river valleys of the Cnidion dubii, 6510 Lowland hay meadows (Alopecurus pratensis, Sanguisorba officinalis) and 1530* Pannonic salt-steppes and salt-marshes.

\section{CO* Ponto-Sarmatic steppes}

From the surface point of view, this habitat has a good representation, being the second after the Turkey oak and

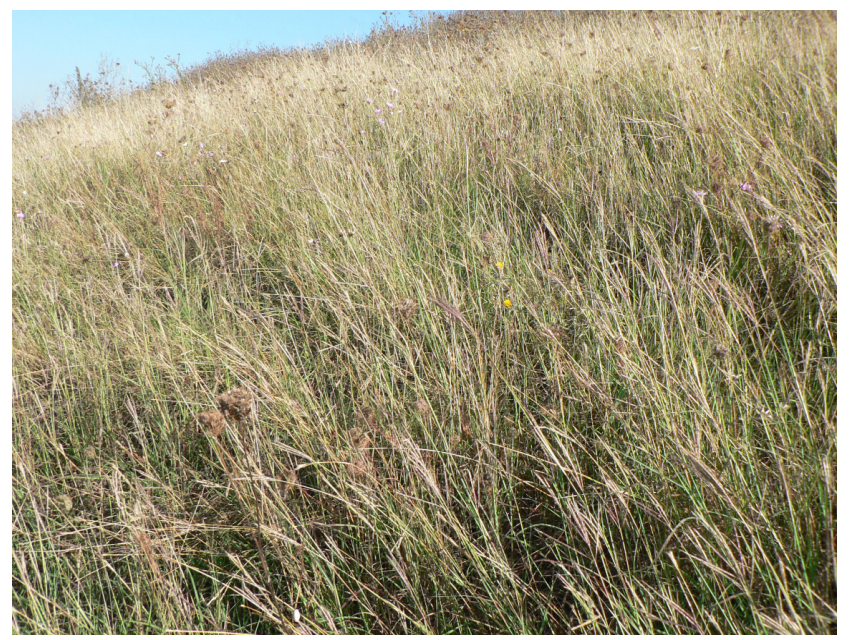

Fig. 1. Physiognomy of the grasslands edified by Dichanthium ischaemum (original)
Hungarian oak forests with Festuca heterophylla in the herbaceous layer.

Starting from spring to the end of summer, the physiognomy of these surfaces is mainly imposed by Festuca valesiaca, which is then replaced by Dichanthium ischaemum (Fig. 1).

Among the species that are typical for the studied sites, we mention: Aegilops cylindrica, Bromus squarrosus, Alyssum desertorum, Medicago minima, Convolvulus arvensis, $C$. cantabricus, Chondrilla juncea, Chrysopogon gryllus, Eryngium campestre, Achillea collina, Arenaria serpyllifolia, Dichantium ischaemum, Cardaria draba, Daucus carota, Linaria vulgaris, Verbascum chaixii subsp. austriacum, Salvia aethiopis, Bromus tectorum, Sisymbrium orientale, Poa bulbosa, Potentilla recta and Teucrium polium subsp. capitatum.

More than $18 \%$ of the surface covered by the two sites present a high conservation status (especially in those areas where vascular species with sozological importance were identified: Ziziphora capitata (Fig. 2), Sternbergia colchiciflora, Salvia aethiopis (Fig. 3), Crucianella angustifolia, Convolvulus cantabricus, Lathyrus sphaericus, etc.), about 60\% a good status and the other $22 \%$ moderate or poor.

Among the association characteristics to this habitat and identified within the site ROSCI0202 Oltenia Forest Steppe, we present the following ones: Medicagini minimae - Festucetum valesiacae and Bothriobloetum ischaemi.

Medicagini - Festucetum valesiacae Wagner 1940

This association was identified in Radovan, Perişor, Mărăcinele, Ciupercenii Noi, Desa settlements. Its phytocoenosis phytocoenosis develop on arid slopes with southern and south-western exposure but also on flat areas. They avoid the slopes with northern exposure.

Bothriochloetum ischaemi (Krist. 1937) (Pop, 1977)

The surfaces covered by Dichanthium ischaemum are easy to be recognized by the end of summer. It was identified in both sites in the following settlements: Radovan, Perişor, Mărăcinele, Tencănău, Castrele Traiane, Verbiciora and Carpen.

The classification of the phytocoenosis within this association was mainly based on the lack of the positive differential species for Medicagini-Festucetum valesiacae, as well as on the differences in terms of floristic compositions,

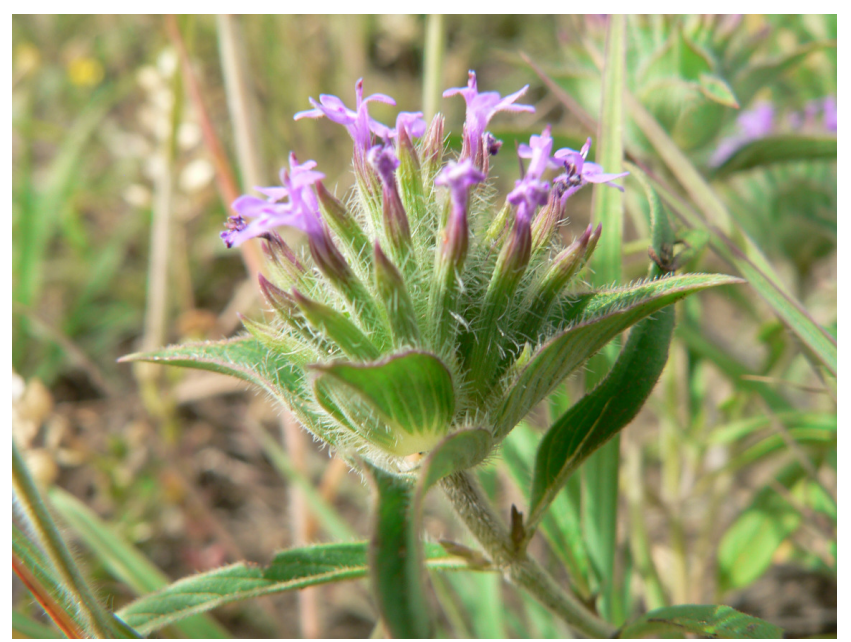

Fig. 2. Ziziphora capitata within the reserve Valea Rea Radovan (original) 
432

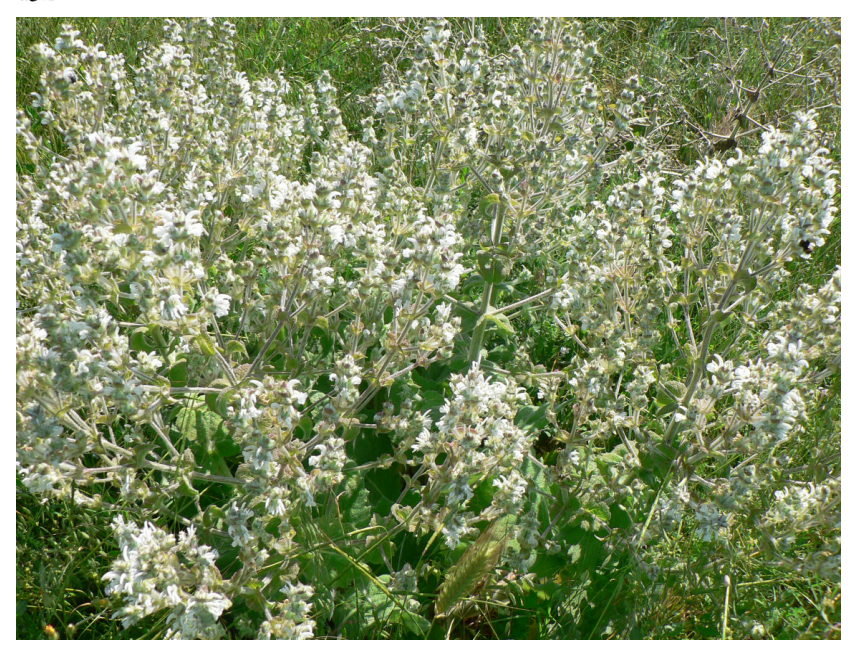

Fig. 3. Salvia aethiopis in the grasslands located at the periphery of Radovan settlement (original)

physiognomy and structure of phytocoenosis, etc.

Other authors assign the grasslands edified by Dichanthium ischaemum to Xeranthemo (cylindracei)-Bothriochloetum ischaemi (Pop G, 1992; Popescu et al., 2001).

Within those surfaces where the conservation status is moderate or poor, it was noticed that the phytocoenosis of this association may evolve towards Cynodonetum dactyloni in the case of climate degradation and arid conditions.

\section{$6260^{*}$ Pannonic sand steppes}

This habitat has a very good representation only within the site ROSCI0039 Ciuperceni - Desa. It is easily recognizable due to Poa species that impose the physiognomy of these areas, among which there can be found communities of associated therophilous species developed on mobile or fixed sands. Among the characteristic species identified by us in the field, we mention: Helichrysum arenarium, Koeleria glauca, Bassia laniflora, Stipa capillata, Cynodon dactylon, Festuca pseudovina, etc.

Among the associations assigned to this habitat, we identified:

\section{Brometum tectori (Bojko, 1934)}

The phytocoenosis of this association vegetate in sandy, ruderalized areas, in acacia forest belts. On the sands from Calafat area, the botanists of the University of Craiova signalled the presence of the sub-association secaletosum Hargitai 1937 (Păun and Popescu, 1972). In Oltenia, it was also identified on the sands located on the left of the Jiu River (Buia and Păun, 1964).

In the site Ciuperceni Desa, this habitat displays the best representation. In the floristic composition of this slightly ruderalized phytocoenosis, there appear certain interesting species from the sozological point of view (eg Silene conica - Fig. 4).

The dominant plants of these grasslands are grazed by domestic animals, mainly sheep, before the emergence of the panicle. In the same time, there Medicago minima grows, which is nutritional for the domestic animals during its first phases of vegetation.

The nutritional value of the grasslands developed on the sands in the area is far from being satisfactory.

Plantaginetum arenariae_Buia et al. (1960)

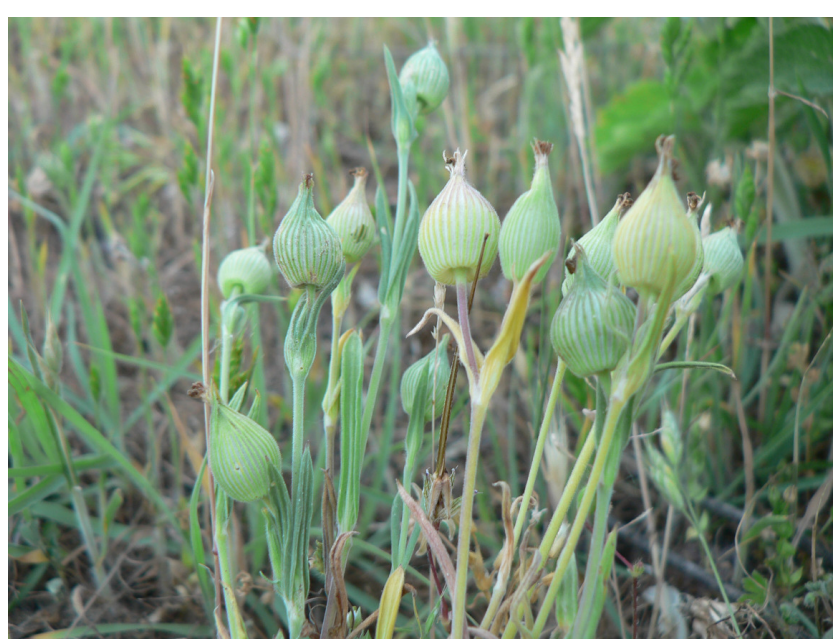

Fig. 4. Silene conica in the neighbourhood of Ciurumela forest (original)

An association is widely spread within the site Ciuperceni - Desa. Besides the dominant species, there are also constantly met other species, such as Poa bulbosa, Digitaria sanguinalis or Bromus tectorum. It is a pioneer association that plays an important role in sand-fixing. A supplementary argument is the increased number of therophilous species.

Although certain surfaces are affected by overgrazing, most of the identified areas (more than 90\%) had a good conservation status of this habitat.

\section{Alluvial meadows of river valleys of the Cnidion dubii}

It gathers the mesohygrophilous meadows that are affected by unfavourable climate conditions during summer. The floristic composition of these surfaces is clearly influenced by the hydric regime of the soil. Much of these surfaces are used by local inhabitants as hayfields. Mowing, in case of these meadows, has a beneficial effect as it prevents degradation. Mowing is however usually practiced in dry years, when the other meadows from the area can no longer be used.

In Romania, the vegetation of this habitat was assigned to:

\section{Caricetum vulpinae (Nowinski, 1927)}

The phytocoenosis of this association were identified as clusters around newly formed pools. Their surfaces vary between $50 \mathrm{~m}^{2}$ (around small pools) and $500 \mathrm{~m}^{2}$ at the interference between the associations of the alliances Glycerio-Sparganion, Magnocaricion elatae and the mesohygrophilous associations of the alliance Agrostion stoloniferae.

On excessively humid lands, especially in the first months of the growing season, in the proximity of the phytocoenosis edified by species characteristic to the alliance Magnocaricion elatae (Caricetum ripariae), the dominant species represents 90-100\%, being accompanied by few but constant species belonging to the alliance Magnocaricion.

The economic value of the phytocoenosis edified by species of Carex is very low. However, these phytocoenosis are grazed by horses and sheep until late in autumn.

The association is widely distributed in Oltenia: Păun (1966, 1967); Zaharia (1972); Păun et al. (1973); Costache (2005) and Răduțoiu (2008).

Poëtum sylvicolae Buia et al. (1959) 
The phytocoenosis of this association develop on low lands with the phreatic layer close to the surface, on brown alluvial gley and semi-gley soils (Buia, 1959). Data referring to this association are mentioned by Păun 1966, Cârțu 1971, Popescu 1974, 1979, Costache 2005 and Rădutoiu 2008.

The floristic composition reflects their mesomesohygrophilous character.

Although there are found numerous weeds in its floristic composition, we cannot speak about a ruderalization of these phytocoenosis.

If in case of the surfaces covered by the phytocoenosis of the association Caricetum vulpinae Nowinski 1927 the conservation status of this habitat is good on about $95 \%$, in case of the meadows edified by Poa sylvicola, the conservation status is good on $75 \%$ while for the remaining $25 \%$ it is moderate. This situation is induced by grazing, the surfaces covered by the phytocoenosis edified by bulbous bluegrass having a great number of forage species.

Agrostietum stoloniferae (Ujvárosi, 1941); Burduja et al. (1956)

The phytocoenosis of this mesohygrophilous association are located in those areas where water maintains at the surface for longer periods. There were studied only those surfaces with a characteristic physiognomy.

The influence of the zoo-anthropogenic factor is also felt in case of these phytocoenosis through the appearance of certain taxa with low economic value, which, on some surfaces, tend to form facieses.

\section{Poëtum pratensis (Răvăruțet al., 1956)}

This meadow grass grows phytocoenosis on sandy and sandyloamy alluvia, with increased moisture in spring, inducing a pronounced mesophilous character.

In Oltenia, the association is mentioned by: Păun (1964); Păun et al. (1973); Roman (1974) - in the south of Mehedinți plateau; Popescu (1974); Maloş (1977) - in the upper basin of the Motru River. It also develops in almost all the regions of the country.

According to the cenotaxonomic classification of this association, there are different opinions. Certain researchers subordinate it to Arrhenatheretalia, Cynosurion cristati (Pop et al., 2000), while others to Agrostion stoloniferae, Molinietalia caeruleae (Costache, 2005).

Due to the intensive grazing in the studied areas covered by this habitat we may assume that the conservation status is seriouslyaffected. This is why, on about half of the surfaces, the conservation status is moderate and sometimes even 'unfavourable-bad' (especially in the case of surfaces covered by Poëtum pratensis). If there will not be taken any measures to control the action of the zoo-anthropogenic factor, the surface covered by this habitat will be considerably reduced.

\section{Lowland hay meadows (Alopecurus pratensis, Sanguisorba officinalis) \\ It is a habitat widely distributed within Central and Northern Europe and less spread in the Mediterranean region. Within the studied area, it was identified on a very small area of the site ROSCI0039 Ciuperceni - Desa, in the Danube floodplain. It does not form phytocoenosis characterised by uniform physiognomy.}

\section{0* Pannonic salt steppes and salt marshes}

This habitat gathers salt steppe meadows and dry forest steppes. On less salted, mesophilous soils, there develop phytocoenosis belonging to the association Achilleo - Festucetum pseudovinae (Magyar, 1928); Soó (1933, 1945), while in more arid areas, there are characteristic the phytocoenosis comprising santonica (Artemisia santonica subsp. monogyna) in their floristic composition. Within this site, there were identified only grasslands assigned to Achilleo - Festucetum pseudovinae (Magyar, 1928) Soó (1933, 1945).

This association is characteristic to slightly salt meadows. They are relatively easy to differentiate from the rest of the meadows characteristic to the area due to their green colour during almost the entire vegetation period.

The physiognomy of the phytocoenosis of this association is given by Festucapseudovina, a caespitose species that makes these meadows more compact. Beside this species, we mention the increased constancy of the species of Achillea (A. collina and $A$. setacea).

In this area, they are used as pasture lands. This aspect is also highlighted by the floristic composition characterized by numerous ruderal species (Convolvulus arvensis, Cardaria draba, Polygonum aviculare, Bromus hordeaceus, etc.).

The conservation status of these surfaces is situated between good and moderate. Phytodiversity might be affected only by spring grazing. Towards summer, these surfaces are avoided by animals due to the lack of good fodder species.

\section{Conclusions}

The meadows assigned to the five habitats present a variable conservation status. About 5\% present a high conservation status, $45 \%$ good, $35 \%$ moderate, $15 \%$ poor. The agricultural capitalization of certain surfaces, overgrazing, mowing before the maturation of the fruits are some of the threats to these habitats. Consequently, there should be taken measures in order to maintain the area and the floristic composition of these grasslands unchanged.

\section{References}

Buia A (1959). Plante rare pentru flora RPR existente în Oltenia. Buletinul Comisiei pentru Ocrotirea Monumentelor Naturii. Ed Acad Române, Bucureşti 13-42.

Buia A, Păun M (1964). Flora şi vegetația nisipurilor. In: Nisipurile Olteniei din stânga Jiului şi valorificarea. Lucrări Ştiințifice Institutul Agronomic "T. Vladimirescu" Craiova 97-163.

Cârțu D (1968). Contribuții la flora Olteniei. Buletinul Ştiințific Universitatea din Craiova 10:63-70.

Cârțu M (1971). Aspecte privind vegetația pajjştilor de luncă din Bazinul Amaradiei. Studii şi Cercetări CCSE Craiova 93-98.

Ciocârlan V (2000). Flora ilustrată a României. Pteridophyta et Spermatophyta. Ed Ceres, Bucureşti.

Ciocârlan V (2009). Flora ilustrată a României. Pteridophyta et Spermatophyta. Ed Ceres, Bucureşti.

Combroux I, Schwoerer C (2007). Evaluarea statutului de conservare a habitatelor şi speciilor de interes comunitar din România-Ghid metodologic. Ed Balcanic, Timişoara.

Costache I (2005). Flora şi vegetația bazinului hidrografic inferior al râului Motru. Teza de doctorat, Bucureşti.

Dihoru G, Negrean G (2009). Cartea roşie a plantelor vasculare din România. Ed Acad Române, București. 
434

Doniță N, Popescu A, Paucă-Comănescu M, Mihăilescu S, Biriş IA (2005). Habitate din România. Ed Tehnică Silvică, București.

Doniță N, Popescu A, Paucă-Comănescu M, Mihăilescu S, Biriş IA (2006). Habitatele din România. Modificări conform amendamentelor propuse de România şi Bulgaria la Directiva Habitate (92/43/EEC). Ed Tehnică Silvică, București.

Gafta D, Mountford O (2008). Manual de interpretare a habitatelor Natura 2000 din România. Ed Risoprint, Cluj-Napoca.

Habitats Directive 92/43/EEC (2015). Habitats Directive 92/43/EEC Council Directive 92/43/EEC of 21 May 1992 on the conservation of natural habitats and of wild fauna and flora. Retrieved 2015 Sept 16 from:http://ec.europa.eu/environment/nature/legislation/habitatsdi rective/.

Ionescu V (1971). Cercetări asupra Characeelor din zona inundabilă a Dunării. Teză de doctorat, București.

Maloş C (1977). Flora şi vegetaţia cormofitelor din bazinul superior al Motrului. Teza de doctorat, Bucureşti.

Păun M (1964). Flora şi vegetația raionului Balş, regiunea Oltenia. Teză de doctorat. Craiova.

Păun M (1966). Materiale pentru flora şi vegetaţia Raionului Balş. Lucrări Ştiințifice Institutul Agronomic "T Vladimirescu” Craiova 6:35-67.

Păun M (1967). Vegetația Raionului Balş, Regiunea Oltenia. Comunicări Ştiinţifice Botanice Bucureşti 6:121-127.

Păun M (1973). Pajiştile mezofile de dealuri din zona subcarpatică a Olteniei. Stud Cercet, Tg Jiu, Intrep Poligr Oltenia, Craiova 4051,194-200.

Păun M, Popescu G (1972). La vegetation des sables de la curbure du Danube(Oltenie). Acta Horti Botanici Bucurestiensis 569-587.
Pop I, Cristea V, Hodişan I (2000). Vegetaţia județului Cluj (Studiu fitocenologic, ecologic, bioeconomic şi ecoproductiv). Contribuţii Botanice 5-255.

Popescu G (1974). Studiul floristic şi geobotanic al Bazinului hidrografic al Bistriței-Vîlcii. Teza de doctorat, Bucureşti.

Popescu G (1979). Noutăţi floristice şi de vegetație din Oltenia. Stud Cercet Biol Veget, Ser Bot Tom 31.1:13-21.

Popescu G, Costache I, Răduțoiu D, Boruz V (2003). Valea Rea Radovan, Dolj district, floristic and vegetation point of great scientific importance. Acta Horti Botanici Bucurestiensis 30:83-94.

Popescu G, Costache I, Răduțoiu D, Gămăneci G (2001). Vegetaţia pajiştilor (Cap 4). In: Ionescu I (Ed). Pajiştile permanente din nordul Olteniei. Ed Universitaria, Craiova pp 116-215.

Răduțoiu D (2008). Flora și vegetația Bazinului Cernei de Olteț. Ed Sitech, Craiova.

Sanda V (1980). Cenotaxonomia şi corologia grupărilor vegetale din România. Stud Com 24, Supliment Ştiințele Naturii Muzeul Brukenthal, Sibiu.

Sanda V (2002). Vademecum cenostructural privind covorul vegetal din România. Ed Vergiliu, București.

Sanda V, Popescu A, Stancu DI (2001). Structura cenotică şi caracterizarea ecologică a fitocenozelor din România. Ed Conphis, Bucureşti.

Sârbu I, Ştefan N, Oprea A (2013). Plante vasculare din România Determinator ilustrat de teren. Ed Victor B Victor, Bucureşti.

Zaharia I (1972). Flora și vegetația Bazinului Gilort de la limita superioară a pădurii pânăla confluența cu Jiul. Teză de doctorat, București. 